\title{
Long-term stability of the hawkmoth fauna (Lepidoptera, Sphingidae) in a protected area of Brazilian Atlantic Rain Forest
}

\author{
Pedro I. Chiquetto-Machado ${ }^{1} \cdot$ Felipe W. Amorim ${ }^{2} \mathbb{D} \cdot$ Marcelo Duarte $^{1}$
}

Received: 11 August 2017 / Accepted: 24 April 2018 / Published online: 30 April 2018

๑) Springer International Publishing AG, part of Springer Nature 2018

\begin{abstract}
Hawkmoths are an important component of tropical ecosystems, with significant roles as herbivores and pollinators. These moths can be used as indicators in biodiversity assessments because they can be easily sampled and identified. However, hawkmoths have seldom been surveyed over the long term for this purpose, especially in the Neotropical region. Considering that long-term datasets are of indisputable importance for understanding and monitoring temporal changes in biodiversity, this study assessed long-term changes in the hawkmoth fauna in a protected Atlantic Rain Forest area over a period of 64 years. We used historical and recent empirical datasets to ask whether faunal-diversity patterns and species composition have changed over time. We used individual- and sample-based rarefaction and extrapolation curves based on Hill number (diversity order of $\mathrm{q}=0$ ) to compare species richness, and the probability version of the abundance-based Chao-Jaccard index to assess beta diversity over time. To assess changes in faunal composition, we conducted a nonmetric multidimensional scaling analysis and performed an analysis of similarities to test whether the community composition has changed. Our results clearly showed long-term stability of the hawkmoth community over the 64 years, despite the growing humaninduced landscape changes that occurred in the region surrounding the study area during the last 6 decades. This study emphasizes the importance of large remnants of Atlantic Forest for long-term maintenance of both functional diversity and ecosystem functioning.
\end{abstract}

Keywords Atlantic Forest $\cdot$ Brazil $\cdot$ Diversity $\cdot$ Insect conservation $\cdot$ Pollinator $\cdot$ Sphingid

\section{Introduction}

Human impacts on the environment have led to accelerated biodiversity loss, with harmful consequences to many ecosystem processes and functions (Vitousek et al. 1997; Butchart et al. 2010; Pereira et al. 2010; Dirzo et al. 2014). Tropical ecosystems face the most critical conditions because

Electronic supplementary material The online version of this article (https://doi.org/10.1007/s10841-018-0061-0) contains supplementary material, which is available to authorized users.

Felipe W. Amorim

amorimfelipe@yahoo.com.br

1 Museu de Zoologia, Universidade de São Paulo, Avenida Nazaré, 481, Ipiranga, São Paulo, SP CEP 04263-000, Brazil

2 Laboratório de Ecologia da Polinização e Interações LEPI, Departamento de Botânica, Instituto de Biociências, Universidade Estadual Paulista "Júlio de Mesquita Filho", Rua Prof. Dr. Antonio Celso Wagner Zanin, 250, Botucatu, SP CEP 18618-689, Brazil they hold most of the world biodiversity and are subject to the highest levels of anthropogenic degradation (Dirzo and Raven 2003; Bradshaw et al. 2009; Gibson et al. 2011). The Brazilian Atlantic Forest is one of the most diverse and threatened ecosystems in the world (Mittermeier et al. 1998; Myers et al. 2000). The Atlantic Forest harbors almost 16,000 plant species, more than 1360 species of non-fish vertebrates, and almost 300 species of mammals; for some groups, the number of endemic species to the Atlantic Forest exceeds $40 \%$ of the known world diversity (Myers et al. 2000; Stehmann et al. 2009; Paglia et al. 2012). However, its original area has been reduced to less than $16 \%$ and the remnant area is scattered in more than 245,000 fragments, most of them (> 80\%) smaller than 50 ha (Ribeiro et al. 2009). Hence, in spite of the great importance of the Atlantic Forest for Brazilian and global biodiversity, its conservation status is critical (Myers et al. 2000; Ribeiro et al. 2009).

Due to the enormous and still poorly known diversity of insects in Brazil (Rafael et al. 2009), the actual rates of insect endemism in the Atlantic Forest are not available. 
However, the outstanding species richness of some insect groups, such as ants ( 800 species), click beetles (1000 species) and longhorn beetles (10,000 species), highlights the importance of this biome for the diversity and conservation of insects (Brown Jr. 1997). Considering that environmental complexity (or heterogeneity) is an important factor affecting animal diversity (Haddad et al. 2001; Brose 2003; Tews et al. 2004; Lassau et al. 2005; Ignatov et al. 2011), the progressive loss of the Atlantic Forest is an obvious threat to the underlying ecological processes involving insects, such as pollination services (Cruz-Neto et al. 2011; Gonçalves et al. 2014).

Hawkmoths (Sphingidae) are among the best-studied lepidopteran groups in the world (Kitching and Cadiou 2000). These moths comprise approximately 1400 species distributed worldwide (van Nieukerken et al. 2011), with the highest diversity concentrated in tropical areas (Kitching and Cadiou 2000). Hawkmoths are an important component of tropical ecosystems, with significant roles as herbivores and pollinators (Haber and Frankie 1989; Darrault and Schlindwein 2002; Johnson et al. 2017). Long-tongued hawkmoths are the sole pollinators of plant species with specialized flowers (i.e., long flower tubes), which rely completely on these moths for sexual reproduction (Nilsson et al. 1987; Martins and Johnson 2013; Johnson and Raguso 2016). A low abundance of long-tongued hawkmoths in the Atlantic Forest may lead to plant-pollinator mismatches (Moré et al. 2012), hindering plant reproduction (Amorim et al. 2014). Since herbivores and pollinators are important components of ecosystem functioning, the conservation of the functional diversity of the Atlantic Forest depends on the conservation of invertebrates such as hawkmoths.

Hawkmoths can be easily sampled and identified, facilitating their use as indicators in biodiversity assessments at local, regional and global scales (see Beck et al. 2006a, b, c, d; Amorim et al. 2009; Ignatov et al. 2011; BallesterosMejia et al. 2013; Camargo et al. 2016). However, despite the indisputable importance of long-term assessments for understanding and monitoring temporal changes in biodiversity (Wolfe et al. 1987; Nilsson et al. 2008; Magurran et al. 2010), hawkmoths have seldom been surveyed for this purpose, particularly in the Neotropical region (Wolda 1983; Wolfe et al. 1987; Conrad et al. 2004; Magurran et al. 2010). The hawkmoth fauna of the Boraceia Biological Station (BBS), a conservation unit situated within the Serra do Mar State Park (SMSP), which is the largest remnant of Atlantic Forest in Brazil, was systematically surveyed in the late 1940s and early 1950s, based on monthly collections (Travassos Filho and Camargo 1958; but also see Duarte et al. 2008). Since then, the area surrounding the BBS has experienced pronounced human population growth and urbanization. The municipality of Salesópolis, where the BBS is located, has doubled in population. The metropolitan region of São Paulo city (which is among the 10 World's largest urban areas), located less than $50 \mathrm{~km}$ from the BBS (Fig. 1), has experienced an eightfold population growth, from 2.6 million in the 1950s to 21.2 million in 2017 (IBGE 2017; Prefeitura de São Paulo 2018, but see also Online Resource 1).

Although the BBS has been a protected area since the 1950s, we do not know whether the human-induced landscape changes over time in its adjoining region have affected its fauna. Also, among the widely known anthropogenic drivers related to insect declines, such as habitat loss and climate change (Dirzo et al. 2014), artificial light at night has been proven to be another challenge for nocturnal insects (MacGregor et al. 2015; Knop et al. 2017; Irwin 2018; Wilson et al. 2018). Especially for hawkmoths, which are long-distance flight insects that can migrate between adjacent habitats and biomes (see Janzen 1986, 1987; Amorim et al. 2009, 2014), surrounding disturbances may affect their faunal dynamics. In this context, the aim of the present study was to assess the long-term dynamics of the hawkmoth fauna in an Atlantic Rain Forest area over a period of 64 years. We used historical (1948-1950) and recent empirical (2012-2013) surveys to ask whether the (1) faunal diversity patterns and (2) species composition have changed over time.

\section{Methods}

\section{Study site and data collection}

The study was conducted in an area of highland Atlantic Rain Forest (Montane Ombrophilous Dense Forest) at the Boraceia Biological Station (BBS; $23^{\circ} 39^{\prime} 15^{\prime \prime} \mathrm{S}, 45^{\circ} 53^{\prime} 22^{\prime \prime} \mathrm{W}$; $850 \mathrm{~m}$ a.s.l.) located in the municipality of Salesópolis, state of São Paulo, southeastern Brazil (Fig. 1). The climate is Subtropical humid (Cfa or Cfb according to Köppen 1948), and the BBS is among the wettest areas in Brazil with a mean annual rainfall above $3300 \mathrm{~mm}$ and not less than $60 \mathrm{~mm}$ per month, even during the driest months (DAEE 2016). The BBS lies within the nature reserve of the Companhia de Saneamento Básico do Estado de São Paulo (Sabesp), which covers an area of 16,450 ha. This reserve is part of the Serra do Mar State Park (SMSP), the largest remnant of Atlantic Forest in Brazil, with a total area of about 332,000 ha (Fundação 2017). The BBS has been maintained as a conservation unit since 1954 (Category ib: Wilderness Area, according to IUCN), 23 years before the establishment of the SMSP in 1977 (see Duarte et al. 2008 for further details).

The historical survey comprised 27 monthly trips for moth collection in light-traps between January 1948 and March 1950 (details in Travassos Filho and Camargo 1958; 
Fig. 1 Location of the Boraceia Biological Station. a Brazil, with the state of São Paulo in dark gray. b State of São Paulo, showing the area detailed in c. c Location of the Boraceia Biological Station (star) in the Serra do Mar State Park (large outlined green area). Forest areas are represented in green, urban areas in dark gray and areas converted to pastures or agricultural landscapes in light gray. Numbers indicate the cities of São Paulo (1), Mogi das Cruzes (2), Biritiba-Mirim (3) and Salesópolis (4). The metropolitan region of São Paulo city includes the four cities. (Color figure online) a

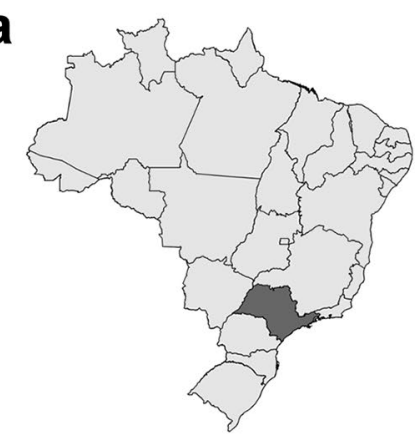

b

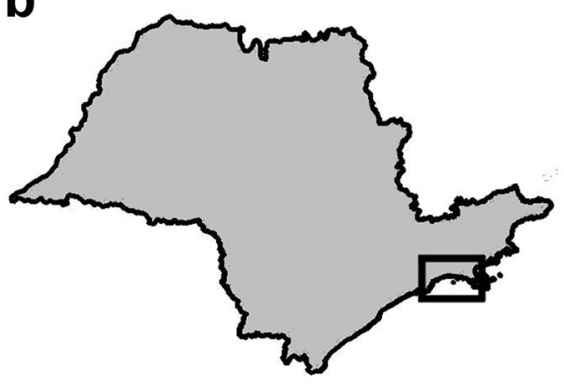

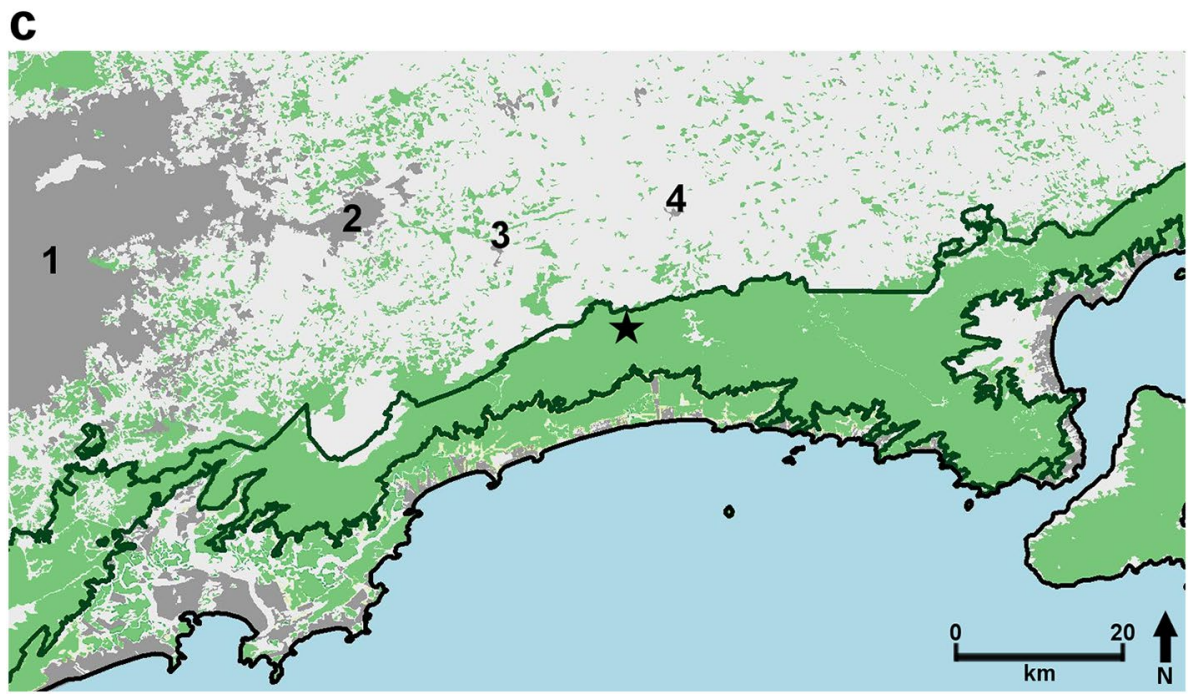

Duarte et al. 2008). Specimens from this survey are available at the Museu de Zoologia da Universidade de São Paulo (MZUSP), and a comprehensive list of the species collected at that time was provided by Duarte et al. (2008). We reassessed this collection at the MZUSP, to update the hawkmoth classification and also to correct possible misidentifications. We carried out genitalia examinations of a group of cryptic species of the genus Manduca, with the goal of generating a more accurate identification of the hawkmoth fauna from the historical survey.

The recent data collections were carried out monthly from July 2012 to June 2013, during four consecutive nights each month (except for December 2012, when only three nights of collections were performed) during the new-moon phase, totalling 47 nights of collection. Hawkmoth collections lasted for $12 \mathrm{~h}$, from late afternoon (18:00 h) until the following morning $(06: 00 \mathrm{~h})$, using eight outdoor lights ( $250 \mathrm{~W}$ mixed UV-rich bulbs) at one of the BBS buildings ("Residência dos Biologistas" sensu Travassos Filho and Camargo 1958, exactly the same location where specimens were collected in the historical survey). We sampled all individuals attracted to the light-traps, collecting them manually or with the aid of insect nets. Moths were killed with an injection of ammonia ( $10 \%$ aqueous solution), administered ventrally in the membrane between the thorax and abdomen. All hawkmoths collected were mounted, labelled and included in the Lepidoptera collection of the MZUSP. Moths were identified with reference to illustrations and identification keys (D'Abrera 1986; Kitching and Cadiou 2000; Moré et al. 2005; Martin et al. 2011; Kitching 2017), and also by examining the genitalia of cryptic species. We followed Kitching and Cadiou (2000) and Kitching (2017) for hawkmoth nomenclature and classification.

\section{Diversity pattern analyses}

To assess whether the diversity pattern changed over time (between historical and recent surveys), we followed Chao et al. (2014) to calculate individual- and sample-based rarefaction and extrapolation curves based on Hill number of the diversity order of $q=0$ (species richness; see Chao et al. 2014). To make realistic comparisons between the assemblages of the two collection periods, we extrapolated the smallest reference sample (the historical survey for individual-based analysis and the recent survey for the samplebased analysis) up to the same number of individuals or samples in the largest reference sample. For the sample-based analysis, we used each monthly sample as a sampling unit (Amorim et al. 2009). To obtain 95\% confidence intervals for all rarefied and extrapolated curves, we used a bootstrap 
method with 200 replications (for details see Hsieh et al. 2016). Rarefaction and extrapolation analyses were performed using the iNEXT package in R programming language (Hsieh et al. 2016).

Sample incompleteness can affect the assessment of species richness (Gotelli and Colwell 2001), since richness is dependent on the abundance, which in turn is highly affected by short-term environmental conditions (see Yela and Holyoak 1997). Even though the historical survey had double the number of sampling months as those in the recent survey, it had only $35 \%$ of the number of hawkmoth individuals collected in 2012-2013 (see "Results"). This suggests that the abundance of hawkmoths collected in the historical survey may have been affected by factors such as fewer collection hours per night or even a selective collection of moths. Hence, in order to compensate for the effect of abundance on the assessment of diversity and improve the evaluation of the faunal changes over time, we calculated Fisher's $\alpha$ diversity index for each month of collection and used Student's $t$-test to compare the mean values of Fisher's $\alpha$ between the two survey periods (see Beck et al. 2006a). Finally, we also assessed the $\beta$-diversity as a measure of species turnover between the two periods. A reliable estimation of $\beta$-diversity must be independent of biases caused by sample size and unequal sampling effort (Barwell et al. 2015). In order to correct for these biases, we used the probability version of the abundance-based Chao-Jaccard index, which incorporates the effect of "unseen" shared species (Chao et al. 2005, 2006, but see also; Melo 2016). For computing $\beta_{\text {Chao-Jaccard }}$ we used the dis.chao function in the CommEcol package in $\mathrm{R}$ (Melo 2016). The $\beta_{\text {Chao-Jaccard }}$-diversity index varies from 0 to 1 , in which values close to one indicate higher species turnover.

\section{Faunal composition analyses}

To assess changes in faunal composition between the two periods, we first conducted a nonmetric multidimensional scaling (NMDS) analysis using the Sørensen similarity index (Legendre and Legendre 1998). Since temperature and rainfall affect the hawkmoth abundance and species-richness distribution throughout the year (Amorim et al. 2009), in order to distinguish the wetter/warmer period (rainfall and temperature above $300 \mathrm{~mm}$ and $18{ }^{\circ} \mathrm{C}$, respectively) from the less wet/colder one (rainfall and temperature below $200 \mathrm{~mm}$ and $16{ }^{\circ} \mathrm{C}$ ), we treated each collection month as a separate sampling unit. For this purpose, we pooled the data from each year of the historical survey together by month. Therefore, each sampling unit corresponds to the total species composition recorded in a specific month regardless of the year of collection. Since the Sørensen coefficient takes into account only incidence data (presence/absence) and we intended to assess the long-term faunal change, this data grouping provides a reliable comparison between the two periods (Legendre and Legendre 1998). In order to compute the NMDS ordination we used the metaMDS function in the vegan package in $\mathrm{R}$ (for details see Oksanen et al. 2017).

To assess how environmental variables affect the distribution of the hawkmoth fauna throughout the year, we fitted temperature and rainfall surfaces to the resulting NMDS ordination. For this, we used the ordisurf function in the vegan package in $\mathrm{R}$ (Oksanen et al. 2017), which applies generalized additive models in the gam function. This function uses thin-plate splines to fit smooth surfaces over the ordination diagram (Wood 2003), allowing better visualization of the effect of environmental variables on the hawkmoth distribution. However, since temperature and rainfall are highly correlated at the BBS (Pearson's correlation $r=0.88, p<0.0001$ ), we present only the results for rainfall, because the pattern observed is quite similar to that observed for temperature. In order to test whether seasonality affected the distribution of hawkmoth species throughout the year, we performed a permutational multivariate analysis of variance (PERMANOVA). This analysis tested for significant differences in the faunal composition between the wetter/ warmer period and the less wet/colder one. We used the adonis 2 function in the vegan package in $\mathrm{R}$ to conduct the PERMANOVA test (Oksanen et al. 2017).

Finally, to test whether the community composition has changed over time, we performed an analysis of similarities (ANOSIM). We used the anosim function in the vegan package in $\mathrm{R}$, which provides results that better reflect the pattern observed in the NMDS ordination (see Oksanen et al. 2017). ANOSIM statistics $(R)$ generate values between 0 and 1 , where a value close to 1 would indicate a distinct separation between the periods (historical and recent surveys) and a value close to 0 would suggest no separation (Clarke 1993). The significance of the $R$ value was calculated by permutation of each month of collection (10,000 permutations), which generates a null distribution of $R$ values (for details see Clarke 1993 and; Oksanen et al. 2017). All analyses were performed in R programming language (R Core Team 2017).

\section{Results}

\section{Historical and recent surveys}

In total, we recorded 76 hawkmoth species in the two sampling periods at the Boraceia Biological Station. Eleven species occurred exclusively in the historical survey, 14 were exclusive to the recent one, and 51 were recorded in both the historical and recent surveys (Online Resource 2). Only one genus (Lintneria) was exclusive to the historical survey, while five genera (Hemeroplanes, Hyles, Isognathus, Madoryx and Orecta) were recorded exclusively in the 
recent survey. All the exclusive genera were represented by a single species, with the exception of Hemeroplanes which was represented by two species (Online Resource 2). During the historical survey, a total of 877 hawkmoths belonging to 62 species were collected. A detailed description of the hawkmoth fauna sampled during the historical survey was provided by Duarte et al. (2008), and an updated and corrected list of species is presented in Online Resource 2.

In the recent survey we sampled a total of 2509 moths belonging to 65 species, distributed in 22 genera, six tribes and three subfamilies (Online Resource 1). Four genera were responsible for $73 \%$ of all moths collected in this survey. Xylophanes was the most abundant genus, totaling about $29 \%$ of all moths collected, followed by Erinnyis (15\%), Adhemarius (14.8\%) and Manduca (14\%). Xylophanes also showed the largest number of species (13 species, $20 \%$ of the total), followed by Manduca with eight species (ca. 12\%). Adhemarius eurysthenes was the most abundant species, with 306 individuals collected in total (ca. 12\%).

\section{Diversity pattern analyses}

Both the individual- and sample-based extrapolation curves showed no difference in species richness between the recent and historical surveys (Fig. 2). However, due to the differences in the number of individuals and sampling months between the historical and recent surveys, rarefied down (interpolation) curves showed an inverse pattern when comparing individual-based curves to sample-based ones (Fig. 2). The historical survey recorded 62 species with only 877 individuals sampled over 27 months, while the recent survey recorded 65 species with 2509 individuals over 12 sampling months. These differences caused the historical survey to show an apparently higher species richness in the individual-based rarefaction and a smaller species richness in the sample-based rarefaction. Nevertheless, Fisher's $\alpha$ diversity index showed no difference between the two surveys ( $t$ $=-1.283 ; 37$ d.f.; $p=0.208$, Fig. 3 ), which also agreed with the very low species turnover $\left(\beta_{\text {Chao-Jaccard }}=0.036\right)$.
Fig. 2 Individual- and samplebased rarefaction (solid lines) and extrapolation (dotted lines) curves with Hill numbers of the diversity order of $q=0$ for the recent (pink) and historical (blue) surveys of hawkmoths at the Boraceia Biological Station. The smallest reference samples (historical survey for the individual-based analysis and the recent survey for the samplebased analysis) were extrapolated up to the same number of individuals or months of collection as the reference sample. Shaded areas show the $95 \%$ confidence intervals for each sample after 200 bootstraps. (Color figure online)
Recent survey (2012-2013) BHistorical survey (1948-1950)

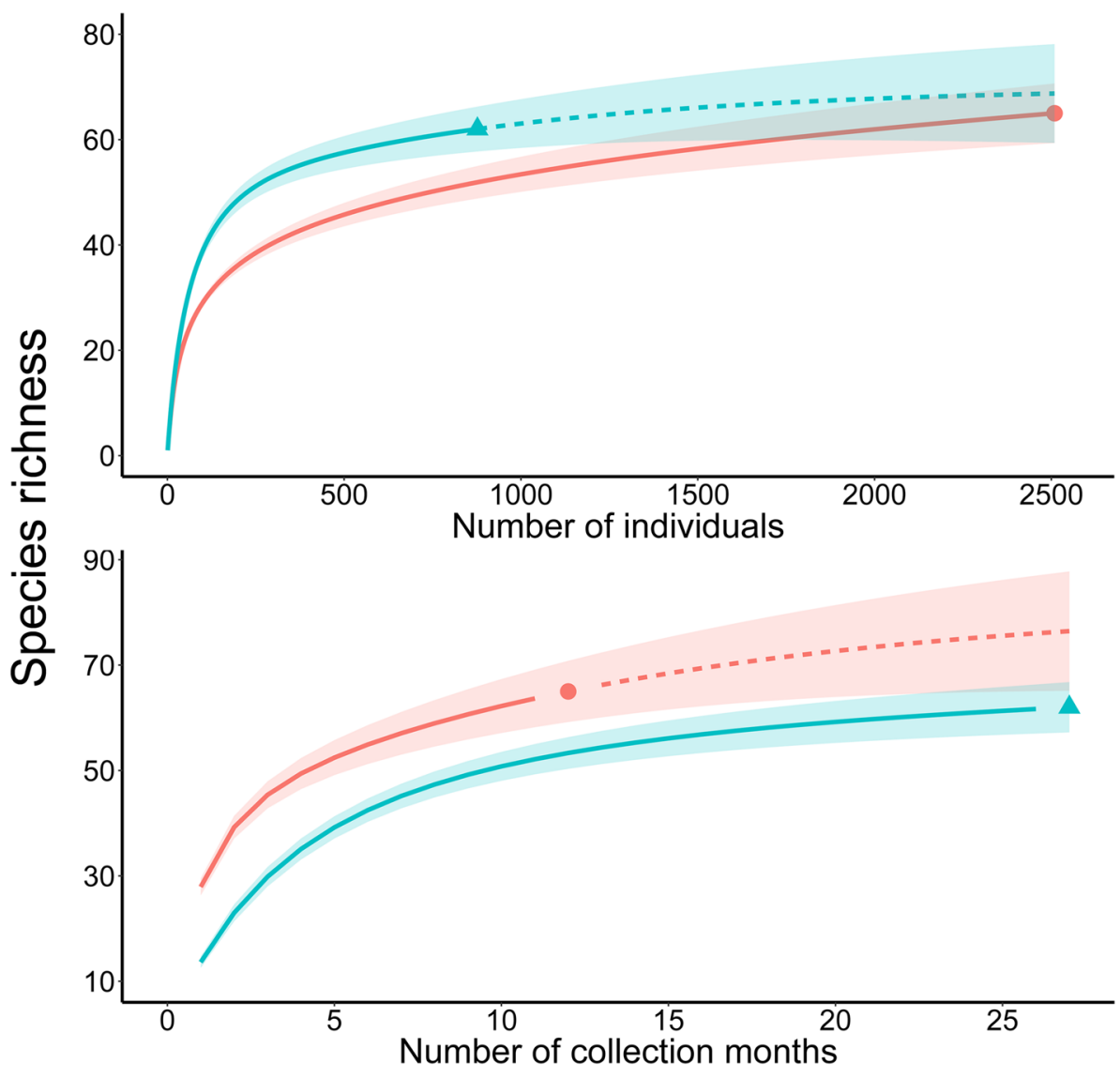




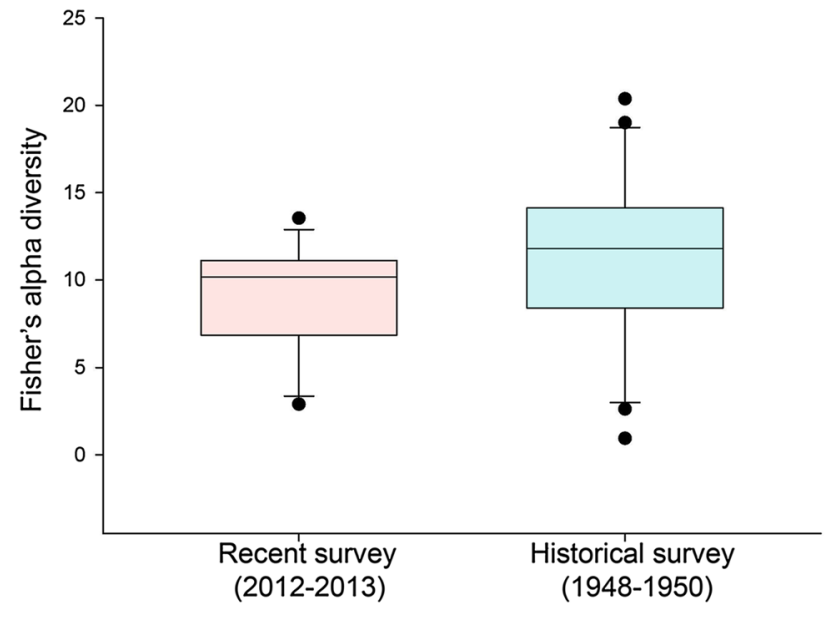

Fig. 3 Comparison of Fisher's $\alpha$ diversity index for each month of collection during the recent and historical surveys at the Boraceia Biological Station. Student's $t$ test showed no difference between the two sampling periods $(t=-1.283 ; 37$ d.f.; $p=0.208)$. Boxes represent $25-75 \%$ percentiles, horizontal line inside each box represents the median, whiskers represent $10-90 \%$ percentiles, and dots represent outliers. (Color figure online)

\section{Faunal composition analyses}

For both the historical and recent surveys, the NMDS analysis revealed a clear separation between the drier/colder months (May to August) and the wetter/warmer ones (stress $0.17, \mathrm{R}^{2}=0.903$; Fig. 4). The PERMANOVA also confirmed the differences between seasons, independently of the survey period (Pseudo- $F=2.06, p=0.0072,10,000$ permutations). However, we found no separation in the overall composition of the hawkmoth fauna between the historical and recent surveys (Fig. 4). The analysis of similarities (ANOSIM) also did not support a separation in the community composition of hawkmoths between the two surveys $(R=0.17$, $p=0.0009,10,000$ permutations).

\section{Discussion}

To the best of our knowledge, this study is the first longterm assessment of hawkmoths in the Neotropical realm. Our results show a clear long-term stability of the hawkmoth community over a period of 64 years in an area within the largest remnant of Atlantic Forest in Brazil. Despite the growing human-induced landscape changes that have occurred in the region surrounding the study area (within a radius of less than $50 \mathrm{~km}$ ) during the last $6 \mathrm{dec}-$ ades, the large size of the forest within which the BBS is located may have provided ideal conditions for long-term maintenance of the hawkmoth fauna. Since habitat disturbance is known to affect the species composition and community structure of hawkmoths in the Brazilian Amazon Forest (Camargo et al. 2016), it is reasonable to infer that small fragments of Atlantic Forest might be under similar pressure, resulting in loss of biodiversity and changes in the faunistic composition and community structure, as observed for other insect groups (Gonçalves et al. 2014; Justino et al. 2016; Shuey et al. 2017).

Forest size is an important determinant of hawkmoth species richness in the tropical rain forest of Southeast Asia (Beck et al. 2006c). In this region, habitat disturbance also affected the hawkmoth faunal composition, leading to a decrease in species of the subfamily Smerinthinae (which comprises short-distance flying species), while those of Macroglossinae (which includes long-distance flying species) showed the opposite pattern (Beck et al. 2006a). In Brazil, highly disturbed Atlantic Forest areas in the Northeast region also have some of the lowest hawkmoth species richness and diversity, compared to other tropical areas in South and Central America (see Amorim et al. 2009). Large remnants of Atlantic Forest are of higher conservation priority (Ribeiro et al. 2009) because they maintain important ecological processes capable of
Fig. 4 NMDS ordination for monthly species composition from historical and recent surveys of the hawkmoth community at the Boraceia Biological Station. Surfaces of rainfall were fitted over the NMDS ordination diagram (stress 0.17 ) to highlight the effect of rainfall on the distribution of hawkmoths throughout the year. (Color figure online)

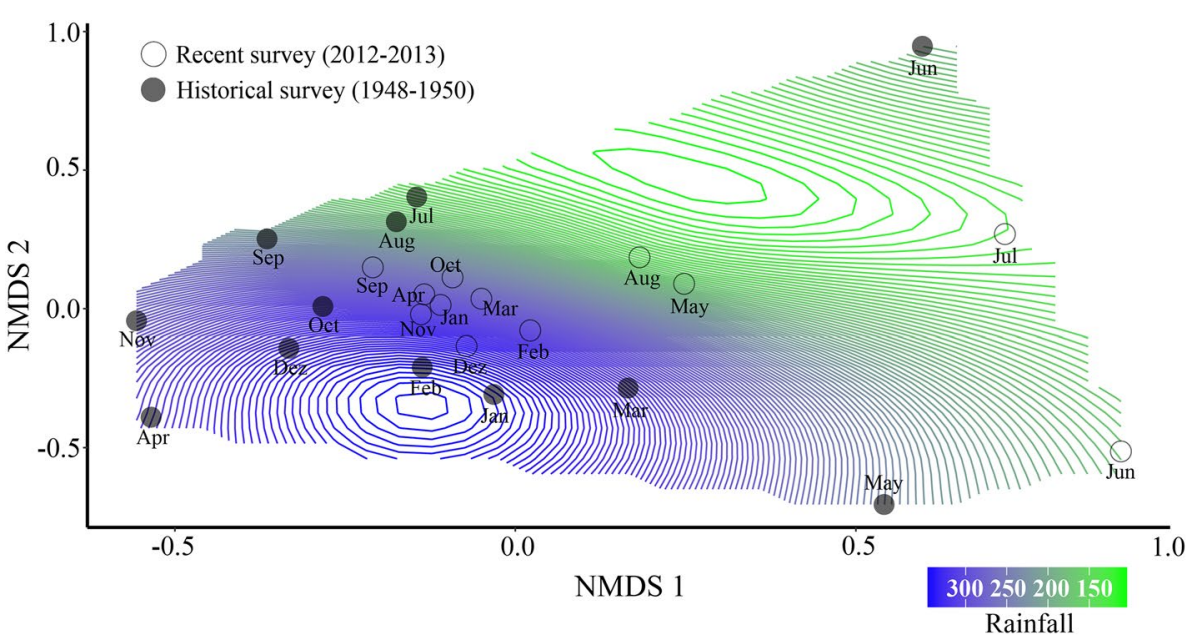


long-term species maintenance (especially the most sensitive species, as was the case with the subfamily Smerinthinae in the Southeast-Asian hawkmoth assemblages studied by Beck et al. 2006a, c).

Of the eight species of Smerinthinae sampled at the BBS, $50 \%$ occurred in both periods of collection, one was exclusive to the historical survey (Adhemarius gagarini) and three were exclusive to the recent survey (Adhemarius daphne, A. palmeri and Orecta lycidas). Of the Macroglossinae, 73\% occurred in both periods, while only 10.3 and $16.7 \%$ were recorded exclusively in the historical and recent surveys, respectively. A similar pattern was observed for species of the subfamily Sphinginae (which comprises the longtongued and long-distance flying species). The very low Chao-Jaccard $\beta$-diversity index, which incorporates the effect of "unseen" shared species, indicated that this variation in species composition over time is related mainly to the occurrence of rare species that might have been present in both surveys but were recorded in only one of them. Some hawkmoth species are likely to have naturally low population densities (Janzen 1984; Kitching and Cadiou 2000) and also were recorded only as singletons (i.e., species represented by a single individual in the whole sample) in other Atlantic Forest areas in the Serra do Mar range (Laroca and Mielke 1975; Marinoni et al. 1999). Similar circumstances were observed for a temperate forest ecosystem in North America: of a total of 571 moth species collected, more than 100 were recorded only as singletons or uniques (i.e., species that occurred in only a single sample), even with a sampling effort as high as 52 nights and more than 14,000 specimens over 2 years (Summerville and Crist 2005).

Long-term changes in the composition of hawkmoth species in a Southeast-Asian tropical rain forest are likely to be related to climate change in addition to habitat disturbance (Beck et al. 2006a). Although we have no empirical support for the supposition that climate change can directly affect the hawkmoth fauna in the Atlantic Forest, it is well known that this factor strongly affects the distribution of plant communities in this biome (Salazar et al. 2007; Colombo and Joly 2010). Since vegetation is an important factor determining hawkmoth distribution and faunal composition (Ignatov et al. 2011; Beck et al. 2006c), the long-term stability of the hawkmoth fauna observed at the BBS highlights the importance of protecting large areas of mature Atlantic Forest such as the SMSP (Ribeiro et al. 2009).

Our results revealed a clear absence of long-term changes in both the faunal composition and species diversity of hawkmoths over a period of 64 years in a Brazilian Atlantic Forest area. Selective collection, however, was probably carried out during the historical survey, since the individualbased rarefaction curve showed a markedly faster increase in species richness, and the opposite pattern was observed for the sample-based rarefaction curve. Notwithstanding this possibility, the extrapolation curves and Fisher's $\alpha$ diversity index (which compensate for the effect of abundance on the assessment of diversity) showed that the alpha diversity has not changed over time. The sole differences observed are related to seasonality, which separated the hawkmoth fauna of the wetter/warmer period from the less wet/colder period in both surveys. Seasonality is an important factor affecting the annual distribution of other hawkmoth assemblages across the Americas (Janzen 1984; Haber and Frankie 1989; Amorim et al. 2009; Vieira et al. 2015; Sazatornil et al. 2016).

But what does the absence of long-term changes in both diversity and composition of hawkmoths (even at the subfamily level) entail for the ecosystem structure and functioning? Hawkmoths are part of complex mutualistic networks with the plants they pollinate (Johnson et al. 2017; Sazatornil et al. 2016), and some of these plants rely exclusively on long-tongued hawkmoths for sexual reproduction. Therefore, the long-term stability of hawkmoths may translate into the maintenance of both plant and pollinator functional diversity in the Atlantic Forest. Functional diversity is directly related to ecosystem functioning (Tilman et al. 1997; Gagic et al. 2015), and pollinator loss, especially the loss of long-tongued species, can lead to high and extreme pollen limitation, hindering the reproduction of both herbs and trees in the Atlantic Forest, including endemic species (Amorim et al. 2014).

In conclusion, even though we found no changes in the hawkmoth community over the last 6 decades, we do not know whether the hawkmoth-plant interaction network also remained stable over time (e.g., Burkle et al. 2013). The Brazilian population has quadrupled since the 1950 s, especially in densely urbanized areas such as the metropolitan region of São Paulo city, which is located less than $50 \mathrm{~km}$ from the BBS. Human-induced changes in the abiotic conditions may affect both plant and pollinator phenologies (see Morellato et al. 2016), which in turn can also affect the structure of plant-pollinator mutualistic networks (MacGregor et al. 2015; Knop et al. 2017). Therefore, future studies might use the pollen load attached to the proboscis and body of the hawkmoths collected in the two surveys at the BBS, in order to assess whether the structure and functioning of the plantpollinator interaction network have changed or remained stable over time.

Acknowledgements We are grateful to Ana Maria Vasques, Geraldo Masélio dos Santos, Firmino Rodrigues Gomes, and Mercedes Águido da Silva (Museu de Zoologia da Universidade de São Paulo) for the logistical support for field trips; to Fabiano Fabian Albertoni and Alessandra Zola Ramin for their indispensable aid during field work; to Carlos Zucco and Fabiano Fabian Albertoni for providing the map used in this article; and to Renato de Oliveira e Silva (Museu de Zoologia da Universidade de São Paulo) for his daily assistance with the curatorial procedures in the Lepidoptera collection. We are also very grateful to two anonymous reviewers and to for their valuable comments and 
suggestions that greatly improved the manuscript. PICM was awarded a scholarship from the Fundação de Amparo à Pesquisa do Estado de São Paulo (FAPESP, Grant 2012/12087-0) for the execution of the research. This study was also funded by FAPESP Grants 2002/138980, 2010/14682-8 and 2011/50225-3, and by the Conselho Nacional de Desenvolvimento Científico e Tecnológico (CNPq, Proc. 484469/2013 to FWA, and Grant 563332/2010-7-SISBIOTA/Rede Nacional de Pesquisa e Conservação de Lepidópteros to MD). MD has been supported by CNPq fellowships (305905/2012-0 and 311083/2015-3). We also thank PROEX/CAPES (Programa de Pós-Graduação em Zoologia, Instituto de Biociências, USP) for providing funds for English revision.

\section{Compliance with ethical standards}

Conflict of interest We have no conflicts of interest to disclose. All necessary permits were obtained for the field study, which did not involve endangered or protected species.

\section{References}

Amorim FW, Ávila RS Jr, Camargo AJA, Vieira AL, Oliveira PE (2009) A hawkmoth crossroads? Species richness, seasonality and biogeographical affinities of Sphingidae in a Brazilian Cerrado. J Biogeogr 36:662-674

Amorim FW, Wyatt GE, Sazima M (2014) Low abundance of longtongued pollinators leads to pollen limitation in four specialized hawkmoth-pollinated plants in the Atlantic Rain forest. Brazil Naturwissenschaften 101:893-905

Ballesteros-Mejia L, Kitching IJ, Jetz W, Nagel P, Beck J (2013) Mapping the biodiversity of tropical insects: species richness and inventory completeness of African sphingids moths. Global Eco Biogeogr 22:586-595

Barwell LJ, Isaac NJB, Kunin WE (2015) Measuring $\beta$-diversity with species abundance data. J Anim Ecol 84:1112-1122

Beck J, Kitching IJ, Linsenmair KE (2006a) Effects of habitat disturbance can be subtle yet significant: biodiversity of hawkmothassemblages (Lepidoptera: Sphingidae) in Southeast-Asia. Biodivers Conserv 15:465-486

Beck J, Kitching IJ, Linsenmair KE (2006b) Measuring range size of South-East Asian hawkmoths (Lepidoptera: Sphinidae): effects of scale, resolution and phylogeny. Global Ecol Biogeogr 15:339-348

Beck J, Kitching IJ, Linsenmair KE (2006c) Determinants of regional species richness: an empirical analysis of the number of hawkmoth species (Lepidoptera: Sphingidae) on the Malesian archipelago. J Biogeogr 33:694-706

Beck J, Kitching IJ, Linsenmair KE (2006d) Wallace's line revisited: has vicariance or dispersal shaped the distribution of Malesian hawkmoths (Lepidoptera: Sphingidae)? Biol J Linn Soc 89:455-468

Bradshaw CJA, Sodhi NS, Brook BW (2009) Tropical turmoil: a biodiversity tragedy in progress. Front Ecol Environ 7:79-87

Brose U (2003) Bottom-up control of carabid beetle communities in early successional wetlands: mediated by vegetation structure of plant diversity? Oecologia 135:407-413

Brown KS Jr (1997) Diversity, disturbance, and sustainable use of Neotropical forests: insects as indicators for conservation monitoring. J Insect Conserv 1:25-42

Burkle LA, Marlin JC, Knight TM (2013) Plant-pollinator interactions over 120 years: loss of species, co-occurrence, and function. Science 339:1611-1615

Butchart SHM, Walpole M, Collen B et al (2010) Global biodiversity: indicators of recent declines. Science 328:1164-1168
Camargo AJA, Camargo NF, Corrêa DCV, Camargo WRF, Vieira EM, Marini-Filho O, Amorim FW (2016) Diversity patterns and chronobiology of hawkmoths (Lepidoptera, Sphingidae) in the Brazilian Amazon rainforest. J Insect Conserv 20:629-641

Chao A, Chazdon RL, Colwell RK, Shen T-J (2005) A new statistical approach for assessing similarity of species composition with incidence and abundance data. Ecol Lett 8:148-159

Chao A, Chazdon RL, Colwell RK, Shen TJ (2006) Abundancebased similarity indices and their estimation when there are unseen species in samples. Biometrics 62:361-371

Chao A, Gotelli NJ, Hsieh TC, Sander EL, Ma KH, Colwell RK, Ellison AM (2014) Rarefaction and extrapolation with Hill numbers: a framework for sampling and estimation in species diversity studies. Ecol Monogr 84:45-67

Clarke KR (1993) Non-parametric multivariate analyses of changes in community structures. Aust J Ecol 18:117-143

Colombo AF, Joly CA (2010) Brazilian Atlantic Forest lato sensu: the most ancient Brazilian forest, and a biodiversity hotspot, is highly threatened by climate change. Braz J Biol 70:697-708

Conrad KF, Woiwod IP, Parsons M, Fox R, Warren MS (2004) Longterm population trends in widespread British moths. J Insect Conserv 8:119-136

Cruz-Neto O, Machado IC, Duarte JA Jr, Lopes AV (2011) Synchronous phenology of hawkmoth (Sphingidae) and Inga species (Fabaceae-Mimosoideae): implications for the restoration of the Atlantic forest of northeastern Brazil. Biodivers Conserv 20:751-765

D’Abrera B (1986) Sphingidae mundi: hawk moths of the world. EW Classey Ltd, Oxford

DAEE (2016) Departamento de Águas e Energia Elétrica, Banco de Dados Hidrológicos, version 20160122.1. http://www.hidro logia.daee.sp.gov.br/Default.aspx. Accessed 31 Mar 2017

Darrault RO, Schlindwein C (2002) Esfingídeos (Lepidoptera, Sphingidae) no Tabuleiro Paraibano, nordeste do Brasil: abundância, riqueza e relação com plantas esfingófilas. Rev Bras Zool 19:429-443

Dirzo R, Raven PH (2003) Global state of biodiversity and loss. Ann Rev Env Resour 28:137-167

Dirzo R, Young HS, Galetti M, Ceballos G, Isaac NJB, Collen B (2014) Defaunation in the Anthropocene. Science 345:401-406

Duarte M, Carlin LF, Marconato G (2008) Light-attracted hawkmoths (Lepidoptera: Sphingidae) of Boracéia, municipality of Salesópolis, state of São Paulo, Brazil. Check List 4:123-136

Fundação F (2017) Governo do Estado de São Paulo, Secretaria do Meio Ambiente, Parque Estadual da Serra do Mar. http://www. parqueestadualserradomar.sp.gov.br/pesm/. Accessed 31 Mar 2017

Gagic V, Bartomeus I, Jonsson T, Taylor A, Winqvist C, Fischer C, Slade EM, Steffan-Dewenter I, Emmerson M, Potts SG, Tscharntke T, Weisser W, Bommarco R (2015) Functional identity and diversity of animals predict ecosystem functioning better than species-based indices. Proc R Soc B 282:20142620

Gibson L, Lee TM, Koh LP, Brook BW, Gardner TA, Barlow J, Peres CA, Bradshaw CJA, Laurance WF, Lovejoy TE, Sodhi NS (2011) Primary forests are irreplaceable for sustaining tropical biodiversity. Nature 478:378-381

Gonçalves RB, Sydney NV, Oliveira PS, Artmann NO (2014) Bee and wasp responses to a fragmented landscape in southern Brazil. J Insect Conserv 18:1193-1201

Gotelli NJ, Colwell RK (2001) Quantifying biodiversity: procedures and pitfalls in the measurement and comparison of species richness. Ecol Lett 4:379-391

Haber WA, Frankie GW (1989) A tropical hawkmoth community: Costa Rican dry forest Sphingidae. Biotropica 21:155-172 
Haddad NM, Tilman D, Haarstad J, Ritchie M, Knops JMH (2001) Contrasting effects of plant richness and composition on insect communities: a field experiment. Am Nat 158:17-35

Hsieh TC, Ma KH, Chao A (2016) Interpolation and extrapolation for species diversity version 2.0.12. https://cran.r-project.org/ web/packages/iNEXT/index.html. Accessed 16 Apr 2017

IBGE (2017) Estimativa da população residente no Brasil e unidades da federação com data de referência em $1^{\circ}$ de julho de 2017. Instituto Brasileiro de Geografia e Estatística. ftp://ftp. ibge.gov.br/Estimativas_de_Populacao/Estimativas_2017/estim ativa_dou_2017.pdf. Accessed 28 Mar 2018

Ignatov II, Janovec JP, Centeno P, Tobler MW, Grados J, Lamas G, Kitching IJ (2011) Patterns of richness, composition, and distribution of sphingid moths along an elevational gradient in the Andes-Amazon region of southeastern Peru. Ann Entomol Soc Am 104:68-76

Irwin A (2018) The dark side of light. Nature 553:268-270

Janzen DH (1984) Two ways to be a tropical big moth: Santa Rosa saturniids and sphingids. Oxford Surv Evol Biol 1:85-140

Janzen DH (1986) Biogeography of an unexceptional place: what determines the saturniid and sphingid moth fauna of Santa Rosa National Park, Costa Rica, and what does it mean to conservation biology? Brenesia 25/26:51-87

Janzen DH (1987) How moths pass the dry season in a Costa Rican dry forest. Int J Trop Insect Sci 8(4-5-6):489-500

Johnson SD, Raguso R (2016) The long-tongued hawkmoth pollinator niche for native and invasive plants in Africa. Ann Bot 117:25-36

Johnson SD, Moré M, Amorim FW, Haber WA, Frankie GW, Stanley DA, Coccuci AA, Raguso RA (2017) The long and the short of it: a global analysis of hawkmoth pollination niches and interaction networks. Funct Ecol 31:101-115

Justino CEL, dos Santos EF, Noll FB (2016) Diversity of Tiphiidae (Insecta: Hymenoptera) in the fragmented Brazilian semi-deciduous Atlantic Forest. J Insect Conserv 20(3):417-431

Kitching IJ (2017) Sphingidae taxonomic inventory. http://sphingidae .myspecies.info/ Accessed 17 Mar 2017

Kitching IJ, Cadiou J-M (2000) Hawkmoths of the world: an annotated and illustrated revisionary checklist (Lepidoptera: Sphingidae). Cornell University Press, Ithaca

Knop E, Zoller L, Ryser R, Gerper C, Hörler M, Fontaine C (2017) Artificial light at night as a new threat to pollination. Nature 548:206-209

Köppen W (1948) Climatología. Fondo de Cultura Económica, México

Laroca S, Mielke OHH (1975) Ensaios sobre ecologia de comunidade em Sphingidae na Serra do Mar, Paraná, Brasil (Lepidoptera). Rev Bras Biol 35:1-19

Lassau SA, Hochuli DF, Cassis G, Reid CAM (2005) Effects of habitat complexity on forest beetle diversity: do functional groups respond consistently? Divers Distrib 11:73-82

Legendre P, Legendre L (1998) Numerical ecology. Elsevier, Amsterdam

MacGregor CJ, Pocock MJO, Fox R, Evans DM (2015) Pollination by nocturnal Lepidoptera, and the effects of light pollution: a review. Ecol Entomol 40:187-198

Magurran AE, Baillie SR, Buckland ST, Dick JMcP, Elston DA, Scott EM, Smith RI, Somerfield PJ, Watt AD (2010) Long-term datasets in biodiversity research and monitoring: assessing change in ecological communities through time. Trends Ecol Evol 25:574-582

Marinoni RC, Dutra RRC, Mielke OHH (1999) Levantamento da fauna entomológica no Estado do Paraná. IV. Sphingidae (Lepidoptera). Diversidade alfa e estrutura de comunidade. Rev Bras Zool 16:223-240

Martin A, Soares A, Bizarro J (2011) A guide to the Hawkmoths of the Serra dos Órgãos, South-eastern Brazil. REGUA Publications, Oxford
Martins DJ, Johnson SD (2013) Interactions between hawkmoths and flowering plants in East Africa: polyphagy and evolutionary specialization in an ecological context. Biol J Linn Soc 110:199-213

Melo AS (2016) Community ecology analyses version 1.6.4. https ://CRAN.R-project.org/package=CommEcol. Accessed 13 Mar 2017

Mittermeier RA, Myers N, Thomsen JB (1998) Biodiversity hotspots and major tropical wilderness areas: approaches to setting conservation priorities. Conserv Biol 12:516-520

Moré M, Kitching IJ, Cocucci AA (2005) Sphingidae: esfíngidos de Argentina. Literature of Latin America, Buenos Aires

Moré M, Amorim FW, Benitez-Vieyra S, Medina AM, Sazima M, Cocucci AA (2012) Armament imbalances: match and mismatch in plant-pollinator traits of highly-specialized long-spurred orchids. PLoS ONE 7:e41878

Morellato LPC, Alberton B, Alvarado S et al (2016) Linking plant phenology to conservation biology. Biol Conserv 195:60-72

Myers N, Mittermeier RA, Mittermeier CG, Fonseca GAB, Kent J (2000) Biodiversity hotspots for conservations priorities. Nature 403:853-858

Nilsson LA, Jonsson L, Ralison L, Randrianjohany E (1987) Angraecoid orchids and hawkmoths in central Madagascar: specialized pollination systems and generalist foragers. Biotropica 19:310-318

Nilsson SG, Franzén M, Jönsson E (2008) Long-term land-use changes and extinction of specialised butterflies. Insect Conserv Diver 1:197-207

Oksanen J, Blanchet FG, Friendly M, Kindt R, Legendre P, McGlinn D, Minchin PR, O'Hara RB, Simpson GL, Solymos P, Stevens MHH, Szoecs E, Wagner H (2017) Ordination methods, diversity analysis and other functions for community and vegetation ecologists version 2.4-3. https://cran.r-project.org/web/packages/vegan /index.html. Accessed 17 Mar 2017

Paglia AP, Fonseca GAB, Rylands AB et al (2012) Annotated checklist of Brazilian mammals, 2nd edn. Occasional Paper No. 6. Conservation International, Arlington

Pereira HM, Leadley PW, Proença V et al (2010) Scenarios for global biodiversity in the 21st century. Science 330:1496-1501

Prefeitura de São Paulo (2018) População recenseada: região metropolitana e municípios. 1950, 1960, 1970, 1980, 1991, 2000 e 2010. Infocidade. http://infocidade.prefeitura.sp.gov.br/htmls/7_popul acao_recenseada_1950_10552.html. Accessed 04 Mar 2018

R Core Team (2017) R: a language and environment for statistical computing. R Foundation for Statistical Computing, Vienna, Austria. http://www.R-project.org. Accessed 31 Jan 2017

Rafael JA, Aguiar AP, Amorim DS (2009) Knowledge of insect diversity in Brazil: challenges and advances. Neotrop Entomol 38:565-570

Ribeiro MC, Metzger JP, Martensen AC, Ponzoni FJ, Hirota MM (2009) The Brazilian Atlantic Forest: how much is left, and how is the remaining forest distributed? Implications for conservation. Biol Conserv 142:1141-1153

Salazar LF, Nobre CA, Oyama MD (2007) Climate change consequences on the biome distribution in tropical South America. Geophys Res Lett 34:L09708

Sazatornil FD, Moré M, Benitez-Vieyra S, Cocucci AA, Kitching IJ, Schlumpberger BO, Oliveira PE, Sazima M, Amorim FW (2016) Beyond neutral and forbidden links: morphological matches and the assembly of mutualistic hawkmoth-plant networks. J Anim Ecol 85(6):1586-1594

Shuey J, Labus P, Carneiro E, Dias FMS, Leite LAR, Mielke OH (2017) Butterfly communities respond to structural changes in forest restorations and regeneration in lowland Atlantic Forest, Paraná, Brazil. J Insect Conserv 21(3):545-557

Stehmann JR, Forzza RC, Salino A, Sobral M, Costa DP, Kamino LHY (2009) Diversidade taxonômica na Floresta Atlântica. In: 
Stehmann JR, Forzza RC, Salino A, Sobral M, Costa DP, Kamino LHY (eds) Plantas da Floresta Atlântica. Instituto de Pesquisas, Jardim Botânico do Rio de Janeiro, Rio de Janeiro, pp 3-12

Summerville KS, Crist TO (2005) Temporal patterns of species accumulation in a survey of Lepidoptera in a beech-maple forest. Biodivers Conserv 14:3393-3406

Tews J, Brose U, Grimm V, Tielbörger K, Wichmann MC, Schwager M, Jeltsch F (2004) Animal species diversity driven by habitat heterogeneity/diversity: the importance of keystone structures. J Biogeogr 31:79-92

Tilman D, Knops J, Wedin D, Reich P, Ritchie M, Siemann E (1997) The influence of functional diversity and composition on ecosystem processes. Science 277:1300-1302

Travassos Filho L, Camargo HFA (1958) A Estação Biológica de Boracéia. Arq Zool 11:1-21

van Nieukerken EJ, Kaila L, Kitching IJ et al (2011) Order Lepidoptera Linnaeus, 1758. In: Zhang ZQ (ed) Animal biodiversity: an outline of higher-level classification and survey of taxonomic richness. Zootaxa 3148:212-221

Vieira KCR, Moraes SS, Chiquetto-Machado PI, Duarte M (2015) Crepuscular and nocturnal hawkmoths (Lepidoptera: Sphingidae) from a fragment of Atlantic rainforest in the state of São Paulo, southeastern Brazil. Fla Entomol 98:342-348

Vitousek PM, Mooney HA, Lubchenco J, Melillo JM (1997) Human domination of Earth's ecosystems. Science 277:494-499

Wilson JF, Baker D, Cheney J, Cook M, Ellis M, Freestone R, Gardner D, Geen G, Hemming R, Hodgers D, Howarth S, Jupp A, Lowe N, Orridge S, Shaw M, Smith B, Turner A, Young H (2018) A role for artificial night-time lighting in long-term changes in populations of 100 widespread macro-moths in UK and Ireland: a citizen-science study. J Insect Conserv. https://doi.org/10.1007/ s10841-018-0052-1

Wolda H (1983) "Long-term" stability of tropical insect populations. Res Popul Ecol 25(suppl 3):112-126

Wolfe DA, Champ MA, Flemer DA, Mearns AJ (1987) Long-term biological data sets: their role in research, monitoring, and management of estuarine and coastal marine systems. Estuaries 10:181-193

Wood SN (2003) Thin-plate regression splines. J R Stat Soc 65:95-114

Yela JL, Holyoak M (1997) Effects of moonlight and meteorological factors on light and bait trap catches of noctuid moths (Lepidoptera: Noctuidae). Environ Entomol 26:1283-1290 